\title{
ANALISIS KEBANGKRUTAN \\ DENGAN MENGGUNAKAN MODEL ALTMAN (Z-Score) \\ Studi Kasus di Perusahaan Telekomunikasi
}

\author{
Pasaman Silaban \\ Fakultas Ekonomi dan Program Magister Manajemen \\ Universitas HKBP Nommensen Medan \\ Email: pasamansilaban@yahoo.co.id
}

\begin{abstract}
The objective of this research is to analyse a company's bancruptcy by the use of Altman Z-Score model. This study used the descriptive quantitative analysis method. The data used are secondary data, the annual financial statements and income statements of each company. Data were analyzed using four X ratio defined by Altman and were used to calculate the $\mathrm{Z}$ score of each company in order to determine its health level. The analysis shows that in 2010 - 2012 the company's health condition was not good. In 2010 the company was in the gray zone, then the next year the company's condition declined, and in 2012 it was at an unhealthy condition/bankrupt. Telkom is in a healthy state and has increased each year, Indosat is in the unhealthy zone with $\mathrm{Z}$ score tends to increase every year. By knowing the health condition of a company, coorporate management is able to evaluate each financial ratio and fix the company's financial performance in order to survive and compete.
\end{abstract}

Keywords: Bancruptcy Analysis, Altman (Z-Score)

Abstrak: Tujuan dari penelitian ini adalah untuk menganalisis Kepailitan perusahaan dengan menggunakan Altman Model Z-Score. Penelitian ini menggunakan metode analisis deskriptif kuantitatif. Data yang digunakan adalah data sekunder, laporan keuangan tahunan dan laporan laba rugi dari masing-masing perusahaan. Data dianalisis dengan menggunakan empat rasio $\mathrm{X}$ didefinisikan oleh Altman dan digunakan untuk menghitung nilai $\mathrm{Z}$ masing-masing perusahaan untuk menentukan tingkat kesehatan. Analisis menunjukkan bahwa pada 2010 - 2012 kondisi kesehatan perusahaan tidak baik. Pada tahun 2010 perusahaan ini berada di zona abu-abu, maka tahun depan kondisi perusahaan menurun, dan pada tahun 2012 itu pada kondisi tidak sehat / bangkrut. Telkom dalam keadaan sehat dan meningkat setiap tahun, Indosat berada di zona yang tidak sehat dengan $\mathrm{Z}$ score cenderung meningkat setiap tahun. Dengan mengetahui kondisi kesehatan suatu perusahaan, manajemen coorporate mampu mengevaluasi setiap rasio keuangan dan memperbaiki kinerja keuangan perusahaan agar dapat bertahan dan bersaing.

Kata kunci: Analisis Kepailitan, Altman (Z-Score)

\section{PENDAHULUAN}

Analisis laporan keuangan dan interpretasinya pada hakikatnya untuk mengadakan penilaian atas keadaan keuangan dan potensi suatu perusahaan, dan dari laporan keuangan tersebut dapat dilakukan analisis berdasarkan rasio keuangan. Rasio-rasio keuangan memberikan indikasi tentang kekuatan keuangan dari suatu perusahaan. Penggunaan alat 
analisis berupa rasio dapat menunjukkan dan memberi gambaran tentang baik atau buruknya posisi keuangan perusahaan yang berakibat pada kegagalan, sehat atau tidaknya suatu perusahaan, apabila dibandingkan dengan rasio tahun sebelumnya atau dengan perusahaan sejenis lainnya.

Terdapat dua macam kegagalan, yakni kegagalan ekonomi dan kegagalan keuangan. Kegagalan ekonomi suatu perusahaan dikaitkan dengan ketidakseimbangan pendapatan dengan pengeluaran. Sementara itu, kegagalan keuangan dalam perusahaan adalah jika perusahaan tersebut tidak mampu membayar kewajibannya pada waktu jatuh tempo meskipun aktiva total melebihi kewajibannya. Salah satu faktor penyebab kebangkrutan perusahaan dimulai dari kegagalan keuangan. Indikator keuangan ini bisa dijadikan alat untuk mengetahui tingkat kebangkrutan suatu perusahaan.

Analisis potensi kebangkrutan Altman, merupakan salah satu alat analisis yang mendalam dan spesifik untuk mengukur tingkat kesehatan dan peluang kebangkrutan suatu perusahaan. Metode Altman dipilih sebagai alat analisa karena kemampuannya untuk memproyeksikan potensi kebangkrutan perusahaan yang diteliti dengan tingkat akurasi yang tinggi, yakni mencapai 80\%-90\%. Bahkan, Altman dalam penelitian berikutnya memastikan bahwa metode tersebut memiliki tingkat akurasi $90 \%$ untuk periode satu tahun mendatang, $80 \%$ untuk periode dua tahun mendatang dan $70 \%$ untuk kurun waktu tiga hingga lima tahun mendatang. (Shim dan Shiegel, 1994)

Pasar telekomunikasi Indonesia mendapat kemajuan signifikan dalam lima tahun terakhir. Sedangkan pertumbuhan pelanggan akan terus berlanjut, seiring langkah operator melakukan ekspansi dalam hal jangkauan, jaringan dan biaya, serta harga peralatan yang semakin murah. Sehubungan dengan itu, penelitian ini menggunakan tiga perusahaan telekomunikasi di Indonesia sebagai studi kasus, yaitu PT XL Axiata, Tbk, PT. Telekomunikasi Indonesia, Tbk dan PT. Indosat, Tbk. Ketiga perusahaan ini dipilih berdasarkan data yang dibutuhkan dalam penelitian ini yakni laporan keuangan yang telah diaudit di Bursa Efek Indonesia. Dalam penelitian ini akan dianalisis tingkat kesehatan masing-masing perusahaan berdasarkan laporan keuangan tahun 2010 - 2012. Hal ini didasarkan pada fenomena yang terjadi pada PT. XL Axiata, yakni proses konsolidasi brand hingga penyelesaian proses demerger pada tahun 2008 oleh TM Group. A demerger is the opposite of an acquisition - a company spins off some business it owns into a completely separate company. A demerger is usually carried out by distributing shares in the business to be spun off to shareholders of the company carrying out the demerger, in proportion to their shareholding in the original company. (Sumber: http://moneyterms.co.uk/, 14 Januari 2013 21:13) Proses tersebut menghasilkan dua entitas terpisah yaitu Telekom Malaysia Berhad dan TM International Berhad yang sekarang telah berganti nama menjadi Axiata Group Berhad, dimana Indocel Holding Sdn. Bhd. secara tidak langsung merupakan anak perusahaan Axiata melalui TM International (L) Limited. Axiata mengakuisisi seluruh kepemilikan saham XL yang dimiliki oleh Khazanah Nasional Berhad, sehingga kepemilikan Indocel Holding Sdn. Bhd. atas XL menjadi 83,80\%.

\section{KAJIAN TEORI}

Kebangkrutan adalah kondisi dimana perushaan mengalami kekurangan atau kesulitan dana untuk menjalankan usaha. Menurut Gibson (2002), "Kegagalan finansial dapat dijelaskan dengan banyak cara. Dapat berarti likuidasi, penangguhan pembayaran 
obligasi dan bunga obligasi, dan kelalaian pada pemabayaran dividen preferen”. Menurut teori ini, kebangkrutan dapat juga dijelaskan sebagai ketidakmampuan perusahaan dalam membayar kewajibannya pada saat jatuh tempo.

Laporan keuangan merupakan media informasi yang merangkum semua aktivitas suatu perusahaan. Laporan keuangan diharapkan bisa memberikan informasi mengenai perusahaan dan digabungkan dengan informasi lainnya, seperti informasi industri dan kondisi ekonomi, sehingga dapat memberikan gambaran mengenai prospek dan risiko perusahaan (Harahap,2004)

Kesulitan keuangan terjadi di mana penyelenggara arus kas yang dimiliki perusahaan tidak cukup untuk membayar kewajiban tetapnya (kredit pinjaman atau beban bunga) dan perusahaan dipaksa untuk melakukan tindakan perbaikan (Ross, Westerfield, 1999). Pengertian kesulitan keuangan dapat diperluas dengan menghubungkannya pada kebangkrutan.

Menurut pendapat Avianti (2000) yang dikutip oleh Iwan (2005) tingkat kebangkrutan akan terjadi jika kurangnya likuiditas sementara dan secara berkelanjutan memilki jumlah yang lebih besar dibandingkan dengan jumlah aktiva yang dimiliki. Sehingga Iwan (2005) menyimpulkan definisi dari kebangkrutan adalah sebagai berikut yaitu kondisi di mana pebisnis tidak mampu membayar kewajibannya dan mengajukan permohonan kepada pengadilan wilayah setempat untuk mereorganisasi hutangnya atau melikuidasi aktiva. Tindakan menyita atas hak milik tanah dari orang berhutang akan diambil alih oleh si penerima atau badan pengawas untuk keuntungan bagi kreditornya. Tindakan ini nantinya mungkin saja akan disalurkan ke The National Bancruptcy Act, dan juga bagi para sukarelawan lainnya.

\section{KAJIAN TEORI}

Biaya Kebangkrutan. Biaya langsung kebangkrutan adalah biaya yang tampak dikeluarkan karena likuidasi atau reorganisasi suatu perusahaan yang tidak sehat antara lain adalah biaya hukum, biaya akuntan, dan biaya pelayanan profesional lainnya. Sedangkan biaya tidak langsung kebangkrutan adalah biaya atas hilangnya profit perusahaan yang diakibatkan oleh potensi kebangkrutan yang telah diketahui sebelumnya, hal ini umumnya disebabkan oleh keengganan konsumen melakukan transaksi dengan perusahaan tersebut (Damodaran,1997).

Kepailitan. Yang dimaksud dengan pailit adalah seseorang yang oleh suatu pengadilan dinyatakan bangkrut dan yang aktivitasnya atau warisannya diperuntukkan untuk membayar utang-utangnya (Abdurrachman, 1991). Kepailitan itu sendiri dapat diartikan sebagai suatu proses di mana seorang debitur yang mempunyai kesulitan keuangan untuk membayar utangnya dinyatakan pailit oleh pengadilan niaga dikarenakan debitur tersebut tidak dapat membayar utangnya. Harta debitur dapat dibagikan kepada para debitur sesuai dengan peraturan pemerintah.

Penyebab Kebangkrutan. Menurut Darsono dan Ashari (2005) penyebab kebangkrutan dapat dibagi menjadi dua yaitu faktor internal dan faktor eksternal. Faktor internal adalah faktor yang berasal dari bagian internal manajemen perusahaan. Sedangkan faktor eksternal bisa berasal dari faktor luar yang berhubungan langsung dengan operasi perusahaan atau faktor perekonomian secara makro. Pradhan (2011) menilai bahwa tindakan untuk memperbaiki keadaan keuangan setelah menerima peringatan dini untuk 
kebangkrutan tergantung pada penggunaan kapasitas sektor tertentu danketersediaan pilihan keuangan perusahaan tersebut

Metode Analisis Kebangkrutan. Beberapa metode yang dapat digunakan untuk analisis kebangkrutan adalah:

1. Model Univariate. Gibson (2002) dalam bukunya mencatat bahwa William Beaver menggunakan model univariate sebagai alat untuk menilai potensi kebangkrutan di dalam penelitiannya. Model ini mengunakan variabel tunggal dimana rasio keuangan akan diuji secara terpisah. Kekurangan dari metode ini adalah pengujiannya yang terpisah. Kombinasi beberapa rasio sulit dilakukan dan bergantung pada penilaian dan pertimbangan analis keuangan.

2. Degree of Relative Liquidity. Metode ini adalah metode yang mengevaluasi kemampuan perusahaan dalam membayar kewajiban jangka pendek. DRL dihitung dengan membagi potensi kas total oleh pengeluaran kas yang diharapkan (Shim dan Siegel, 1994)

3. Indeks Lambda. Indeks Lambda adalah rasio yang berfokus pada dua komponen likuiditas, yaitu saldo kas jangka pendek dan kredit yang tersedia, untuk mengukur profitabilitas suatu perusahaan. Lambda pada masa tertentu adalah penjumlahan dari cadangan likuid awal perusahaan dan arus dana bersih dibagi dengan ketidakpastian yang terkait pada arus kas (Shim dan Siegel, 1994). Keunggulannya adalah fokusnya pada kunci faktor likuiditas, yang dapat menunjukkan ketersediaan kredit yang tidak digunakan dan arus kas. Namun, kelemahan terbesar dari indeks Lambda adalah ketergantungannya pada peramalan pendapatan.

4. Metode Altman. Pengukuran rasio Altman yaitu untuk mengetahui potensi kebangkrutan menggunakan perhitungan Z-Score. Metode Altman dipilih sebagai alat analisa karena kemampuannya untuk memproyeksikan potensi kebangkrutan perusahaan yang diteliti dengan tingkat akurasi yang tinggi, yakni mencapai 80\%90\%. Bahkan, Altman dalam penelitian berikutnya memastikan bahwa metode tersebut memiliki tingkat akurasi 90\% untuk periode satu tahun mendatang, 80\% untuk periode dua tahun mendatang dan 70\% untuk kurun waktu tiga hingga lima tahun mendatang. (Shim dan Shiegel, 1994). Pendapat senada juga diberikan Hayes, dkk (2010) serta Odipo dan Sitati (2010) bahwa model ini memiliki tingkat akurasi yang tinggi yaitu di atas $80 \%$.

Analisis Altman (Z-Score). Formula Z-Score untuk memprediksi kebangkrutan dari Altman merupakan sebuah formula multivarian yang digunakan untuk mengukur tingkat kesehatan finansial sebuah perusahaan (Altman, 2002). Altman menemukan lima jenis rasio keuangan yang dapat dikombinasikan untuk melihat perbedaan antara perusahaan yang bangkrut dan tidak bangkrut. Model Altman (Z-Score) adalah suatu model yang sangat terkenal untuk memprediksi kebangkrutan atau kesulitan keuangan pada perusahaan. Pada tahun 1968 seorang bernama Edward Altman merupakan peneliti awal yang mengkaji pemanfaatan analisis rasio keuangan sebagai alat untuk memprediksi kebangkrutan. Dalam penelitiannya Altman menggunakan 33 pasang perusahaan yang bangkrut dan perusahaan yang tidak bangkrut yang berjumlah 66 perusahaan sebagai sampel. Model yang disusunnya secara tepat mampu mengidentifikasi 90\% kasus kebangkrutan pada satu tahun sebelum kebangkrutan terjadi. Dengan menggunakan teknik multivariate discriminant analysis. Formula yang dihasilkan pada tahun 1968 dikenal dengan model A (Altman,1968) 
Fungsi diskriminan metode Altman yang dikenal dengan model A adalah sebagai berikut:

$$
\mathrm{Z}=1,2 \mathrm{X}_{1}+1,4 \mathrm{X}_{2}+3,3 \mathrm{X}_{3}+0,6 \mathrm{X}_{4}+1,0 \mathrm{X}_{5} \text { (Altman, 1968) }
$$

Pada tahun 1984, Altman kembali melakukan penelitian di berbagai negara. Penelitian ini menggunakan dimensi internasional, sehingga Z-Score nya berubah menjadi formula sebagai berikut:

$$
Z=0,717 X_{1}+0,847 X_{2}+3,107 X_{3}+0,42 X_{4}+0,998 X_{5} \text { (Altman, 1984) }
$$

Cut off point yang ditentukan pada metode Altman model $\mathrm{B}$ ini juga mengalami perubahan. Untuk model ini Altman memberikan cut off point sebagai berikut:

Jika $\mathrm{Z}<1,23$ maka dideteksi perusahaan sedang berada di ambang kebangkrutan/berpotensi besar akan mengalami kebangkrutan (tidak sehat).

Jika 1,23 $<\mathrm{Z}<2,90$ maka dideteksi perusahaan berada pada zona abu (grey area), di mana kondisi finansial perusahaan harus diperhatikan dengan seksama.

Jika Z > 2,90 maka dideteksi bahwa finansial perusahaan dalam kondisi sehat (tidak bangkrut).

Model tambahan yang dikenal dengan model B yang dihasilkan oleh Altman pada tahun 1984. Model ini dapat diterapkan pada perusahaan manufaktur non publik dan perusahaan pribadi/privat. Model ini merupakan model yang lebih umum daripada model awal yang digunakan pada tahun 1968 yang hanya dapat diterapkan pada perusahaan yang sahamnya diperdagangkan di bursa efek. Sedangkan model B dapat diterapkan baik pada perusahaan emiten maupun non emiten tanpa dampak yang berarti bagi kinerja perusahaan (Altman,2002)

Dalam model-model di atas, Altman menggunakan simbol X, di mana masingmasing $\mathrm{X}$ mempresentasikan rasio keuangan yang dipakai. Adapun lima rasio keuangan yang digunakan tersebut menurut Adnan M dan Taufiq M (2005) ialah: (1) Likuiditas, (2) Usia perusahaan dan profitabilitas kumulatif, (3) Produktivitas, (4) Aktivitas, (5) Rasio perputaran modal.

Berikut penjelasan lengkap dari masing-masing rasio $\mathrm{X}$ tersebut di atas:

1. Rasio $\mathrm{X}_{1}$ (Working Capital to Total Aktiva). Rasio ini digunakan untuk mengukur likuiditas aktiva perusahaan terhadap total kapitalisasinya. Dan likuiditas dari total aktiva dan posisi modal kerja (neto). Selain itu, rasio likuiditas juga digunakan untuk mengukur kemampuan perusahaan dalam memenuhi kewajiban jangka pendek yang jatuh tempo.

2. Rasio $\mathrm{X}_{2}$ (Retained Earnings/Total Asset). Rasio ini digunakan untuk mengukur profitabilitas kumulatif dan juga untuk mendeteksi kemampuan perusahaan dalam menghasilkan keuntungan, ditinjau dari kemampuan perusahaan yang bersangkutan dalam memperoleh laba dibandingkan dengan kecepatan perputaran aktivitas operasi sebagai ukuran efisiensi usaha. Rentabilitas atau profitabilitas menunjukkan kemampuan perusahaan untuk menghasilkan laba selama periode tertentu.

3. Rasio $\mathrm{X}_{3}$ (Earning Before Taxes to Total Aktiva). Rasio ini digunakan untuk mengukur produktivitas yang sebenarnya dari aktiva perusahaan. Selain itu juga merupakan cerminan dari rasio profitabilitas yaitu rasio yang dapat mengukur kemampuan/efektivitas manajemen dalam menghasilkan laba selama periode tertentu. Selain itu juga merupakan rasio yang dapat mengukur kemampuan dari modal yang diinvestasikan dalam keseluruhan aktiva untuk menghasilkan keuntungan bagi semua investor termasuk pemegang saham dan obligasi.

4. Rasio $\mathrm{X}_{4}$ (Market Value of Equity to Book Value of Debt). Rasio ini digunakan untuk mengukur seberapa banyak aktiva perusahaan yang nilainya dapat turun sebelum 
jumlah utang lebih besar daripada aktivanya dan perusahaan menjadi apilit (insolvent). Rasio aktivitas adalah rasio yang mengukur seberapa efektif perusahaan dalam menggunakan sumber-sumbernya. Sering juga digunakan dalam bentuk persamaan $\mathrm{Net}$ Worth /Total Debt. Rasio ini mengukur kemampuan perusahaan dalam memberikan jaminan kepada setiap utang melalui modalnya sendiri.

5. Rasio $\mathrm{X}_{5}$ (Total Aktiva Turnover). Rasio ini digunakan untuk mengukur kemampuan manajemen dalam menghadapi kondisi persaingan. Selain itu juga merupakan bagian dari rasio aktivitas. Rasio tersebut mengukur efisiensi perubahan dalam pemakaian total aktivanya untuk menghasilkan penjualan.

Penelitian Terdahulu. Penelitian sebelumnya yang mendasari penulis untuk melakukan penelitian ini antara lain:

1. Penelitian yang dilakukan oleh Deni Juandani dengan judul "Analisis Prediksi Kebangkrutan Bank Umum Swasta Nasional dengan Menggunakan Metode Altman” pada tahun 2009. Penulis melakukan menggunakan laporan keuangan tahun 2008 dari masing-masing objek studi yaitu bank swasta nasional. Tujuan Penelitian Untuk mengetahui dan menganalisis kebangkrutan di seluruh bank umum swasta nasional dengan menggunakan metode Altman. Operasional Variabel: $\mathrm{X}_{1}$ Rasio modal kerja terhadap total aktiva., $\mathrm{X}_{2}$ Rasio laba ditahan terhadap total aktiva, $\mathrm{X}_{3}$ Rasio EBIT terhadap total aktiva, $\mathrm{X}_{4}$ Rasio modal sendiri terhadap total utang, $\mathrm{X}_{5}$ Rasio penjualan terhadap total aktiva. Menggunakan metode Deskriptif kuantitatif di mana penelitian dilakukan hanya untuk mengetahui tingkat kinerja keuangan seluruh bank umum swasta nasional dengan menggunakan model Altman. Dan penulis dapat meyimpulkan dan mengumpulkan nilai z dari seluruh bank umu swasta nasional di Indonesia dan mampu mengetahui kinerja keuangan masing-masing objek penelitian.

2. Jurnal yang berjudul "Coorporate Failure Prediction: a Study of Public Listed Companies in Malaysia." Oleh Shuk Wern Ong, dkk. Penulis melakukan penelitian untuk memprediksi kebangkrutan perusahaan-perusahaan terbuka di Malaysia.Tujuan penelitian untuk mengetahui dan mengantisipasi kemungkinan kebangkrutan bagi perusahaan publik Malaysia dengan menggunakan persamaan diskriminan Altman. Dengan operasionalisasi variabel $\mathrm{X}_{1}$ Rasio modal kerja terhadap total aktiva., $\mathrm{X}_{2}$ Rasio laba ditahan terhadap total aktiva, $\mathrm{X}_{3}$ Rasio EBIT terhadap total aktiva, $\mathrm{X}_{4}$ Rasio modal sendiri terhadap total utang, $\mathrm{X}_{5}$ Rasio penjualan terhadap total aktiva. Menggunakan metode Deskriptif kuantitatif di mana penulis hanya memaparkan kinerja keuangan perusahaan publik yang menjadi objek penelitian. Penulis memaparkan bahwa dampak krisis keuangan dunia menyebabkan banyak perusahaan publik di Malaysia memasuki zona abu dan zona tidak sehat.

3. Tesis dengan judul "Pengaruh Potensi Kebangkrutan Altman Terhadap Pergerakan Harga Saham Perusahaan Manufaktur Terbuka di Bursa Efek Indonesia” oleh Ailando Siregar pada tahun 2008. 116 perusahaan manufaktur publik yang terdaftar di BEI dan memenuhi kriteria penelitian. Tujuan penelitian untuk mengetahui dan menganalisis pengaruh dari faktor-faktor fundamental dengan menggunakan model potensi kebangkrutan Altman terhadap pergerakan harga saham perusahaan manufaktur terbuka di Bursa Efek Indonesia. Operasionalisasi Variabel, $\mathrm{X}_{1}$ Rasio modal kerja terhadap total aktiva. $\mathrm{X}_{2}$ Rasio laba ditahan terhadap total aktiva, $\mathrm{X}_{3}$ Rasio EBIT terhadap total aktiva, $\mathrm{X}_{4}$ Rasio modal sendiri terhadap total utang, $\mathrm{X}_{5}$ Rasio penjualan terhadap total aktiva, dan Y Harga saham. Menggunakan metode deskriptif kuantitatif yang menerangkan hubungan, menguji hipotesis, membuat prediksi serta mendapatkan 
makna dan implikasi dari suatu masalah. Sifat penelitian adalah explanatory. Penulis dapat menunjukkan serta mengurutkan perusahaan manufaktur terbuka dengan nilai altman terendah hingga tertinggi, dan disimpulkan bahwa rata-rata perusahaan manufaktur di BEI dapat diramalkan akan mengalami kegagalan dan harga saham ratarata berada di atas harga perdana saham.

4. Penelitian oleh Haryadi Sarjono dengan judul "Analisis Laporan Keuangan Sebagai Alat Prediksi Kemungkinan Kebangkrutan dengan Model Diskriminan Altman pada Sepuluh Perusahaan Properti di Bursa Efek Jakarta”. Tujuan penelitian mengetahui kondisi kesehatan perusahaan. Operasionalisasi Variabel, Rasio $\mathrm{X}_{1}$ (Working Capital to Total Asset, Rasio $\mathrm{X}_{2}$ (Retained Earnings/Total Asset), Rasio $\mathrm{X}_{3}$ (Return on Asset , Rasio $\mathrm{X}_{4}$ (Equity to Debt), Rasio $\mathrm{X}_{5}$ (Asset Turnover). Menggunakan metode deskriptif kuantitatif untuk mengukur kinerja keuangan perusahaan berdasarkan analisis rasio keuangan melalui model Z-Score untuk public manufacture. Terdapat lima dari sepuluh perusahaan properti di BEJ dalam kondisi keuangan yang tidak sehat/bangkrut, 2 berada di zona abu dan 3 berada pada kondisi sehat.

5. Penelitian oleh Marko S Hermawan, dkk dengan judul "The Degree of Company Vulnerability Using Altman Model: A Survey of Public Listed Companies in Indonesia". Tujuan penelitian mengetahui potensi kebangkrutan dan performa perusahaan publik yang terdaftar di BEJ. Operasionalisasi Variabel: Rasio $\mathrm{X}_{1}$ (Working Capital to Total Asset), Rasio $\mathrm{X}_{2}$ (Retained Earnings/Total Asset), Rasio $\mathrm{X}_{3}$ (Return on Asset) Rasio $\mathrm{X}_{4}$ (Equity to Debt) Rasio $\mathrm{X}_{5}$ (Asset Turnover). Menggunakan metode deskriptif kuantitatif untuk mengetahui potensi kebangkrutan perusahaan. Terdapat banyak perusahaan publik di Indonesia yang berada pada zona abu, dan zona tidak sehat.

6. Hasil Penelitian oleh Saša Muminović (2013), Revaluation and Altman `s Z-score -the Case of the Serbian Capital Market. Mengetahui seberapa signifikan pengaruh revaluation terhadap perhitungan model Altman Z-score. Operasionalisasi Variabel: $X 1=$ working capital/total assets, $X 2=$ retained earnings/total assets, $X 3=$ earnings before interest and taxes/total assets , X4= market value of equity/book value of total liabilities, $X 5=$ sales/total assets, $Z=$ overall index. Menggunakan metode deskriptif kuantitatif di mana melakukuakn uji pengaruh revaluation terhadap nilai altman Zscore dan eliminasi revaluation, akibat perubahan akuntasnsi akan meningkatkan akurasi model altman $Z$ score. Hasil analisis menunjukkan: Revaluation makes original Altman `s $Z$ score worse as a consequence of the fact that Model's parameter $X 3$ is based on profitability and it has the highest impact. The profitability always decreases if the value of the assets increases and the value of profit (gain) remains the same. On the other hand debt to equity ratio in Model (X4) is improved with revaluation, but it has three times lower impact.

\section{METODE}

Penelitian ini dimulai dengan suatu analisis teori rasio keuangan sebagai titik tolak pemikirannya. Fakta dan data yang diperoleh selama penelitian diolah, dianalisis, dan ditarik kesimpulannya lebih lanjut dengan dasar teori yang ada sehingga memberi gambaran mengenai keadaan keuangan PT XL Axiata, Tbk, PT Telekomunikasi Indonesia, Tbk dan PT Indosat, Tbk. Penelitian ini dilakukan dengan maksud menganalisis dan mengevaluasi kinerja dan tingkat kesehatan perusahaan. 
Adapun variabel operasional yang digunakan dalam penelitian ini disajikan pada Tabel 1.

Tabel 1. Variabel Operasional

\begin{tabular}{|c|c|c|c|}
\hline Variabel & Konsep Variabel & Indikator & Skala \\
\hline $\mathrm{X}_{1}$ & $\begin{array}{l}\text { Likuiditas aktiva } \\
\text { perusahaan terhadap } \\
\text { total kapitalisasi. }\end{array}$ & $\begin{array}{l}\text { Working Capital To Total Asset } \\
=\frac{\text { current asset }- \text { current liabilities }}{\text { total asset }}\end{array}$ & Rasio \\
\hline $\mathrm{X}_{2}$ & $\begin{array}{l}\text { Profitabilitas } \\
\text { perusahaan dalam } \\
\text { periode tertentu }\end{array}$ & $\begin{array}{l}\text { Retained earning To Total Asset } \\
=\frac{\text { Re tained Earning }}{\text { Total Asset }}\end{array}$ & Rasio \\
\hline $\mathrm{X}_{3}$ & $\begin{array}{l}\text { Produktivitas riil } \\
\text { dari aktiva } \\
\text { perusahaan }\end{array}$ & EBIT To Total Asset $=\frac{E B I T}{\text { Total Asset }}$ & Rasio \\
\hline $\mathrm{X}_{4}$ & $\begin{array}{l}\text { Pengukuran aktivitas } \\
\text { perusahaan }\end{array}$ & Capital Ratio $=\frac{\text { Total Equity }}{\text { Total Debt }}$ & Rasio \\
\hline
\end{tabular}

Populasi dalam penelitian ini adalah perusahaan telekomunikasi di Indonesia. Dari populasi tersebut maka diambil beberapa sampel yang dijadikan sebagai objek studi penelitian, dengan teknik non-probability sampling dengan metode purposive-sampling yaitu teknik pengambilan sampel berdasarkan pada pertimbangan tertentu di mana penulis secara sengaja mengambil sampel dengan argumentasi yang bisa dipertanggungjawabkan secara ilmiah. (Eriyanto,2007). Dalam hal ini sampel yang diambil berdasarkan pada laporan keuangan perusahaan yang terdaftar di Bursa Efek Indonesia dan telah diaudit secara lengkap sehingga dipilih tiga sampel dalam penelitian yaitu PT XL Axiata, Tbk, PT Telekomunikasi Indonesia, Tbk, PT Indosat, Tbk.

Untuk menganalisis potensi kebangkrutan masing-masing perusahaan digunakan Altman Z-Score model B untuk perusahaan public non-manufacture dengan menggunakan empat rasio yang akan dihitung dengan melakukan pengolahan data sekunder yaitu neraca konsolidasi dan laporan laba rugi tahun 2010-2012 dari masing-masing perusahaan.

\section{HASIL DAN PEMBAHASAN}

Rasio-rasio tersebut meliputi working capital to total asset ratio, retained earning to total asset ratio, EBIT to total asset ratio, capital ratio.

Formula yang digunakan untuk menghitung Z-Score untuk perusahaan public nonmanufacture adalah:

$$
\mathrm{Z}=6,56 \mathrm{X} 1+3,26 \mathrm{X} 2+6,72 \mathrm{X} 3+1,05 \mathrm{X} 4 \text { (Altman, 1995) }
$$

Dimana:

$\mathrm{X}_{1}$ adalah working capital to total asset ratio,

$\mathrm{X}_{2}$ adalah retained earning to total asset ratio,

$\mathrm{X}_{3}$ adalah EBIT to total asset ratio,

$\mathrm{X}_{4}$ adalah equity to total asset ratio.

Cut off point yang ditentukan dalam model Altman ini adalah : 
Jika $\mathrm{Z}<1,11$ maka dideteksi bahwa finansial perusahaan dalam kondisi tidak sehat (bangkrut).

Jika 1,1 $<\mathrm{Z}<2$,6 maka dideteksi perusahaan berada pada zona abu (grey area), di mana kondisi finansial perusahaan harus diperhatikan dengan seksama.

Jika Z > 2,6 maka dideteksi bahwa finansial perusahaan dalam kondisi sehat (tidak bangkrut).

Analisis Tingkat Kesehatan Masing-masing Perusahaan. Untuk menganalisis tingkat kesehatan digunakan empat rasio keuangan yang selanjutnya akan digunakan dalam perhitungan Z-Score. Berikut analisis dan hasil perhitungan masing-masing rasio keuangan yang berkaitan dengan Altman Z-Score setiap perusahaan yang diteliti untuk periode tahun 2010-2012:

Tabel 2. Analisis dan hasil perhitungan masing-masing rasio keuangan yang berkaitan dengan Altman Z-Score (2010-2012)

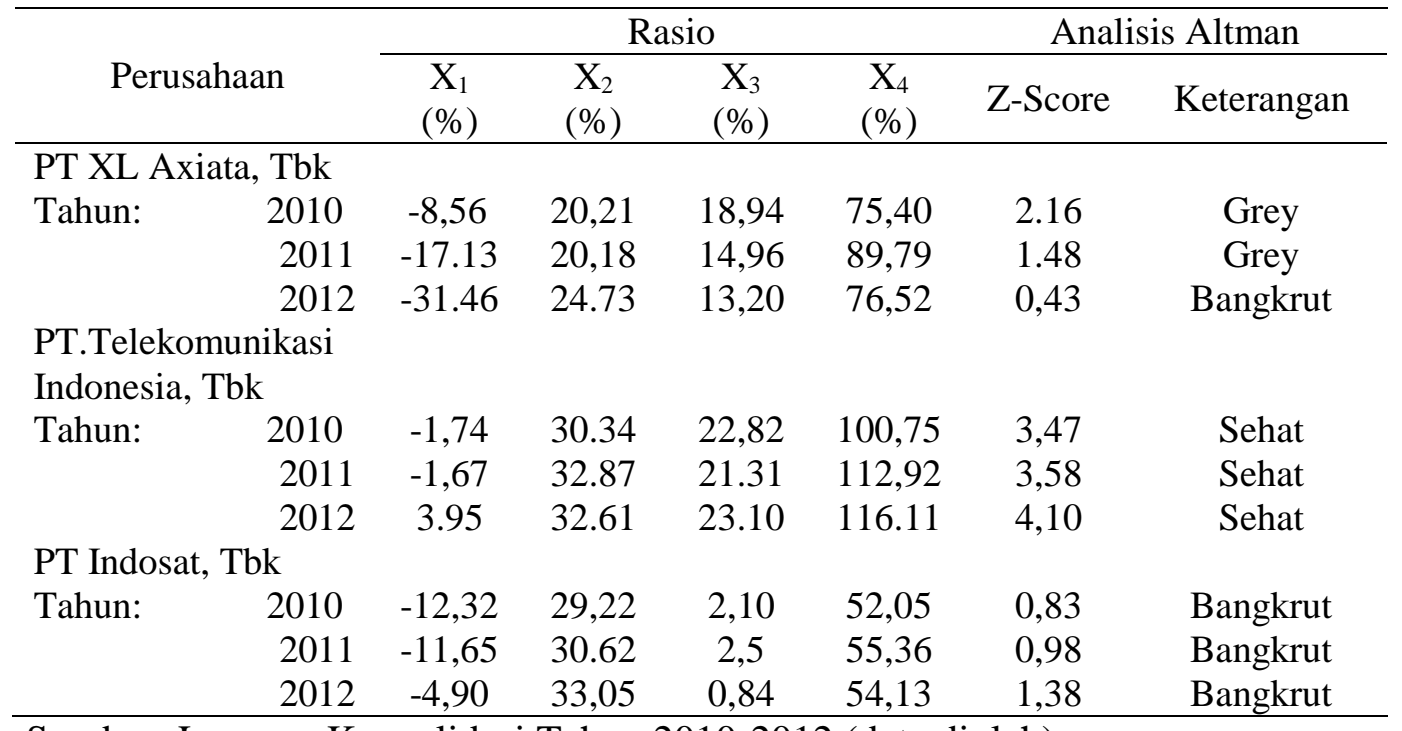

Sumber: Laporan Konsolidasi Tahun 2010-2012 (data diolah)

Dari Tabel 2, dapat dilihat bahwa mulai tahun 2010-2011 kondisi keuangan PT XL Axiata, Tbk berada pada zona abu yaitu kondisi keuangan perusahaan harus diperhatikan secara seksama. Dari tabel diatas dapat kita lihat kondisi keuangan perusahaan mengalami penurunan setiap tahunnya. Pada tahun 2012 perusahaan berada pada kondisi tidak sehat/bangkrut dengan nilai Z-Score 0.43 . Hal ini diakibatkan adanya divestasi oleh salah satu pemegang saham utama XL melalui penawaran saham pada investor institusi, sehingga hal ini menyebabkan meningkatnya porsi kepemilikan saham publik.

Seperti yang tertera pada tabel diatas, kondisi kesehatan PT Telekomunikasi Indonesia, Tbk sangat baik yakni berada pada posisi sehat, setiap tahunnya terjadi peningkatan. Artinya kondisi perusahaan setiap tahunnya semakin baik dan semakin berkembang. Terutama pda tahun 2012 kenaikan posisi keuangan perusahaan cukup tinggi hingga nilai $\mathrm{Z}$ nya meningkat cukup besar yaitu sebesar 0,5 menjadi 4,10.

Seperti yang terlihat pada tabel di atas bahwa nilai Z PT Indosat, Tbk pada tahun 2010-2012 meningkat dari tahun ke tahun. Namun posisi keuangan perusahaan selalu berada di zona tidak sehat/bangkrut. 
Dari Tabel 2 dapat dipaparkan bahwa di antara ketiga perusahaan di atas PT Telkom, Tbk merupakan perusahaan dengan kondisi kesehatan perusahaan yang paling baik, hingga 2012 pihak manajemen mampu membenahi kondisi kinerja keuangan perusahaan dan tetap berada di zona sehat dan meningkat setiap tahunnya.

Sedangkan XL sendiri memiliki kinerja keuangan yang tidak sehat. Hal ini terjadi karena proses konsolidasi brand yang terjadi di perusahaan. Namun pihak manajemen menanggapi hal ini dengan cukup baik karena seperti yang tertera pada tabel di atas, kondisi keuangan perusahaan setiap tahun menunjukkan penurunan. Pada tahun 2012 perusahaan berada pada kondisi tidak sehat/bangkrut dengan nilai Z-Score 0.43 . Hal ini diakibatkan adanya divestasi oleh salah satu pemegang saham utama XL melalui penawaran saham pada investor institusi, sehingga hal ini menyebabkan meningkatnya porsi kepemilikan saham publik.

Jika dilihat dari kenaikan tiap rasio keuangan yang digunakan, XL memiliki kinerja yang sangat baik, dapat dilihat dari masing-masing rasio $\mathrm{X}$ jika dibandingkan dengan Telkom dan Indosat, terutama pada rasio $\mathrm{X}_{3}$ dan $\mathrm{X}_{4}$ persentase peningkatan rasionya sangat tinggi. Sebaliknya, Indosat justru mengalami peningkatan kinerja setiap tahunnya, kondisi keuangan Indosat setiap tahunnya berada di zona tidak sehat/bangkrut. Namun pada tahun 2012 peningkatan kinerja perusahaan meningkat cukup baik, walaupun posisi keuangan dan kesehatan perusahaan masih berada di zona bangkrut namun peningkatan yang terjadi menunjukkan bahwa manajemen perusahaan mampu membenahi kondisi keuangan perusahaan secara perlahan. Dari hasil perhitungan yang telah dilakukan, maka perlu dijelaskan secara rinci kondisi kesehatan tiap-tiap perusahaan yang menjadi objek studi dilihat dari masing-masing rasionya.

1. Working Capital To Total Asset Ratio

Secara keseluruhan nilai rasio ini pada tiap perusahaan fluktuatif dan bernilai negatif. Nilai rasio yang negatif menggambarkan bahwa ada claim utang lancar atas fixed asset perusahaan. Dari ketiga objek studi, nilai rasio XL semakin negatif dari tahun ke tahun terutama di tahun 2012, rasionya menurun sebesar $14,33 \%$, hal ini terjadi karena penurunan nilai net working capital perusahan sedangkan nilai total asset perusahaan semakin meningkat. Sementara Telkom dan Indosat mengalami peningkatan nilai rasio setiap tahunnya, bahkan pada tahun 2012 nilai rasio Telkom bernilai positif.

2. Retained Earning To Total Asset Ratio

Untuk rasio ini ketiga perusahaan dinilai cukup baik karena nilai retained earning perusahaan meningkat setiap tahunnya. Nilai rasio ketiga perusahaan mengalami penurunan pada tahun 2011 dikarenakan oleh financial crisis yang terjadi. Namun secara keseluruhan rasionya cukup baik. Dari ketiga perusahaan, Telkom memilki rasio yang paling besar, namun kinerja keuangan XL dapat dikatakan baik karena dari ketiga perusahaan ini, XL merupakan perusahaaan yang rasionya mengalami peningkatan yang paling tinggi. Pada tahun 2012 kenaikan rasio XL sebesar 4,55\% sedangkan Telkom mengalami penurunan sebesar 0,26\% dan Indosat mengalami penuingkatan sebesar 2,43\%. Kenaikan rasio ini mengakibatkan nilai saham perusahaan tetap stabil walaupun kesehatan perusahaan dinilai tidak sehat.

3. EBIT To Total Asset Ratio

Rasio ini digunakan untuk mengukur kemampuan perusahaan dalam menghasilkan laba selama periode tertentu. XL pada tahun 2011 mengalami penurunan hampir 4\%, kemudian pada tahun 2012 kembali menurun menjadi 13,20\%. 
Telkom pada tahun 2011 mengalami penurunan rasio sebesar 1,51\%, kemudian pada tahun 2012 rasionya meningkat sebesar 1,79\%. Sedangkan Indosat mengalami penurunan nilai rasio pada tahun 2012 menjadi 0,84\% dari tahun sebelumnya 2,50\%.

4. Market Value Of Equity To Total Debt Ratio

Pada tahun 2012 perusahaan mengalami penurunan nilai rasio yaitu XL sebesar 13,27\%, dan Indosat sebesar 3,31\%, sedangkan Telkom mengalami peningkatan sebesar $12,17 \%$. Rasio ketiga perusahaan cenderung fluktuatif, namun tetap berada di posisi positif.

Rasio ini menggambarkan kemampuan perusahaan mengelola kewajibannya dengan menggunakan ekuitas yang dimiliki perusahaan. Secara keseluruhan Telkom merupakan perusahaan yang memiliki nilai rasio yang paling baik, namun XL merupakan perusahaan yang memiliki progress rasio yang sangat baik. Peningkatan angka rasionya sangat tinggi setiap tahunnya jika dibandingkan dengan Telkom dan Indosat.

Rasio-rasio di atas secara keseluruhan mempengaruhi angka perhitungan Altman ZScore masing-masing perusahaan. Hasil perhitungan Z-Score pada masing-masing perusahaan menunjukkan bahwa XL berada pada zona abu pada tahun 2010 dan mengalami penurunan di tahun berikutnya sehingga perusahaan berada pada kondisi tidak sehat pada tahun 2011 dan 2012. Telkom sendiri berada pada kondisi sehat pada tahun 2010 hingga 2012. Bahkan peningkatan yang terjadi cukup baik. Sedangkan Indosat berbanding terbalik dengan XL, pada tahun 2010-2012 perusahaan berada pada zona bangkrut. Namun tingkat kesehatan dan kondisi keuangan mengalami peningkatan setiap tahunnya.

Berdasarkan hasil penelitian dan pembahasan sebelumnya dapat disimpulkan bahwa kinerja PT Telkom, Tbk dan PT Indosat, Tbk secara garis besar dalam keadaan sehat atau tidak berpotensi bangkrut hal ini dtunjukkan dari hasil pengujian menggunakan metode Zscore Altman. Sedangkan kinerja keuangan PT XL Axiata, Tbk cenderung menurun dan berpotensi bangkrut menurut metode Z- score Altman. Oleh karena itu perlu dilakukan peningkatan kinerja keuangan dimasa yang akan datang agar perusahaan tersebut berada pada kondisi sehat.

Dilihat dari laporan keuangan tahunan perusahaan yang sering mengalami penurunan pada rasio daya laba maka secara umum dapat ditawarkan bahwa : Masalah efektivitas dalam menjalankan kegiatan operasional perusahaan harus diperhatikan baik dari kegiatan penjualan, pembelian dan kegiatan lainnya, sehingga mengurangi terjadinya penurunan laba perusahaan dan seetiap tahunnya perusahaan dihadapkan dengan peningkatan bebanbeban perusahaan seperti gaji karyawan, harga pokok penjualan dll, sehingga perusahaan harus mencari alternative agar penjualan terus meningkat sehingga tidak ada masalah untuk likuiditas perusahaan.

Berdasarkan pembahasan yang diuraikan di atas, bahwa hasil penelitian ini telah memaparkan kasus untuk 3 perusahaan yang berada pada sektor telekomunikasi, dan hasilnya memberikan dukungan atas penelitian-penelitian yang telah dilakukan sebelumnya dimana metode Z- score Altman dapat dipergunakan sebagai acuan dalam memprediksi kebangkrutan suatu perusahaan. Oleh karena itu, walaupun penelitian ini berbeda objek dengan penelitian terdahulu, namun hasil yang diberikan tidak jauh berbeda antar perusahaan di sektor yang berbeda. 


\section{PENUTUP}

Dari hasil penelitian PT XL Axiata, Tbk pada tahun 2010 - 2012 kondisi kesehatan perusahaan tidak baik, pada tahun 2010 perusahaan berada di zona abu, yang artinya kondisi keuangan perusahaan harus diperhatikan dengan seksama, kemudian pada tahun berikutnya kondisi perusahaan semakin menurun hingga pada tahun 2011 - 2012 berada pada kondisi tidak sehat/bangkrut. Perlu ditambahkan bahwa di antara ketiga perusahaan di atas PT Telkom, Tbk merupakan perusahaan dengan kondisi kesehatan perusahaan yang paling baik. Sedangkan XL sendiri pada tahun 2010 perusahaan berada pada zona abu namun kondisi keuangan perusahaan memburuk di tahun-tahun berikutnya hingga perusahaan berada di zona tidak sehat/bangkrut. Indosat justru mengalami peningkatan kinerja setiap tahunnya. Nilai Z perusahaan mengalami peningkatan setiap tahunnya. Namun tetap berada di zona tidak sehat/bangkrut.

\section{DAFTAR RUJUKAN}

Abdurrahman. (1991) Masalah Pencabutan Hak Atas Tanah dan Pembebasan Tanah Indonesia, Bandung: PT Citra Bakti

Adnan, Muhammad A \& Taufiq, Muhamad I. (2001). Analisis Ketepatan Prediksi Metode Altman Terhadap Terjadinya Likuiditas Pada Lembaga Perbankan. Jurnal Ekonomi \& Auditing, Volume 5 (2), Desember. Yogyakarta: Fakultas Ekonomi Universitas Islam Indonesia Yogyakarta.

Altman, E.I. (1968) "Financial ratios, discriminant analysis and prediction of corporate bancruptcy”. Journal of Finance, Vol XXIII (4) hal. 589-609

Altman, E.I., J. Hartzell, and M. Peck. (1995) Emerging Markets Coorporate Bonds : A Scoring System. New York: Salomon Brothers Inc.

Altman, E.I. (2002) Corporate Distress Prediction Models in a Turbulent Economic and Basel II Environment. Credit Rating: Methodologies Rational and Default Risk. Risk Books. London

Damodaran, Aswath. (1997) Corporate Finance Theory and Practice. New York: John Wiley \& Sons, Inc.

Darsono, dan Ashari. (2005) Pedoman Praktis Memahami Laporan Keuangan. Yogyakarta: Andi

Eriyanto. (2007) Teknik Sampling Analisis Opini Publik. Yogyakarta, LKIS Yogyakarta.

Gibson, Charles H. (2002) Financial Reporting and Analysis: Using Financial Accounting Information. Boston: PWS-Kent Publishing Company

Harahap, Sofyan Syafri. (2004) Analisis Kritis atas Laporan Keuangan. Jakarta: PT Raja Grafindo Persada.

Hayes, Suzanne K. Kay A. Hodge and Larry W. Hughes. (2010). “A Study of the Efficacy of Altman's Z To Predict Bankruptcy of Specialty Retail Firms Doing Business in Contemporary Times”. Economics \& Business Journal: Inquiries \& Perspectives 3 (1). University of Nebraska at Kearney and Central Washington University.

Iwan, Mohammad. (2005) "Bancruptcy Prediction Model with Zeta Optimal Cut-Off Score to Correct Type I Errors”. Gadjah Mada International Journal of Business. Januari - April. Vol 7, (1) hal. 41-68

Model in Prediction Of Financial Distress: A Case Of Companies Quoted in The Nairobi Stock Exchange. Journal of Business Failure Prediction. 
Ross, Stephen A. Westerfield, Randolph W. Dan Jaffle, Jeffrey. (1999) Corporate Finance, 5th ed. The McGraw-Hill Company.

Saša Muminović (2013) "Revaluation and Altman`s Z-score -the Case of the Serbian Capital Market”. International Journal of Finance and Accounting 2013, 2 (1) hal 13-18, Slovenia.

Shim, Jae K., Joel G. Siegel. (1994) Tools For Executives, CFO: The Vest-Pocket CFO, Buku Ketiga. Jakarta: PT. Gramedia Pustaka Utama.

Odipo M.K. and Sitati, A. (2010) Evaluation Of Applicability Of Altman's Revised

Pradhan, Roil. (2011) "Prediction Of Z Score For Private Sector Banking Firms". International Referred Research Journal. 2 (22). ISSN-0975-3486, RNI: RAJBIL 2009/30097. 